\title{
Eksegesis Mazmur 73: Pergumulan Orang Benar Tentang Kemakmuran Orang Fasik
}

\author{
Samgar Setia Budhi \\ Sekolah Tinggi Teologi Kalimantan \\ Korespondensi: samgarbudhi@sttkalimantan.ac.id
}

\begin{abstract}
Abstrak
Penderitaan orang benar dan kemakmuran orang fasik seringkali menjadi pergumulan bagi orang yang beriman. Isu ini sesungguhnya ada sepanjang zaman yaitu sejak zaman Alkitab hingga masa kini.Pergumulan ini dapat berimplikasi kepada iman orang percaya di tengah kehidupannya. Oleh sebab itu diperlukan pemahaman yang benar tentang Allah dan kehendak-Nya melalui kebenaran firman-Nya. Mazmur 73 adalah salah satu teks Alkitab yang membicarakan tentang isu penting ini. Melalui studi kualitatif kajian biblika murni dengan pendekatan teori tafsir literal-gramatikalhistorikal-kontekstual dan eksegesis, serta dengan mempertimbangkan bentuk sastra dari Mazmur didapatkan pemahaman bahwa masalah hati merupakan dasar dari munculnya pergumulan tentang kemakmuran orang fasik. Hati yang cemburu terhadap kemakmuran orang fasik seringkali menggoyahkan keyakinan orang beriman akan kebaikan Allah. Tetapi ketika orang beriman memiliki persekutuan yang intim dengan Allah, maka ada perspektif baru yang akan dibukakan oleh Allah tentang pergumulannya. Sesungguhnya Allah berdaulat atas hidup manusia. Akhir hidup orang fasik sudah ditentukan. Tetapi bagi orang beriman, penyertaan Tuhan adalah kebaikan yang tertinggi karena dengan penyertaan Tuhan hidup orang beriman akan selalu dalam pemeliharaan-Nya.
\end{abstract}

Kata-kata kunci: Eksegesis, Mazmur, Hati, Kemakmuran, Kebaikan Allah.

\begin{abstract}
The suffering of godly men and the prosperity of the wicked often become the struggle for faithful men. This issue has been around for all ages, from the biblical times until today. This struggle could have implications for the faith of the believers within one's life. Therefore the sound understanding of God and His will through the scripture is needed. Psalm 73 is one of the Bible texts that is talking about this important issue. Through a pure biblical qualitative study with literal-grammatical-historical-contextual interpretation and exegesis theory approach, and also considering the literature style of the Psalm it is found that the base of the struggle from the existence of prosperity among the wicked is the problem from the heart. An envious heart toward the wealthiness of the wicked often moved the faith of the godly men about the kindness of the Lord. But when believers have an intimate relationship with the Lord, then new perspectives will be opened by God concerning the struggle. God is sovereign towards men's life. The end of the wicked lives has been determined. On the contrary, for those who live in faith, the presence of God is the highest goodness because the life of a believer along with the Lord with him will always be under His nurture.
\end{abstract}

Keywords: Exegesis, Psalm, Heart, Prosperity, the Goodness of The Lord. 


\section{Pendahuluan}

Penderitaan orang benar dan kemakmuran orang fasik seringkali menjadi persoalan bagi orang yang beriman. Pertanyaan yang muncul adalah, "Mengapa orang benar menderita tetapi orang fasik makmur?" Robert L. Deffinbaugh menulis bahwa pertanyaan ini telah membuat orang percaya bingung dan sebaliknya orang skeptis menjadi senang selama berabad-abad. ${ }^{1}$ Meskipun tidak mudah untuk menjawabnya, pertanyaan itu tetap pertanyaan penting yang harus dijawab karena mempunyai implikasi bagi kehidupan iman orang percaya. Menurut Deffinbaugh, pertanyaan itu bertujuan untuk apologetik dan memelihara iman kita di tengah berbagai pencobaan hidup. ${ }^{2}$

Sesungguhnya isu tentang penderitaan orang benar dan kemakmuran orang fasik sudah ada dari zaman Alkitab hingga masa kini. Pada zaman Alkitab tokoh-tokoh seperti Ayub (Kitab Ayub), Yeremia (Yer. 11:8-12:6), dan pemazmur (Mzm. 37, 73) yang bergumul tentang hal ini. Pada masa kini tidak sedikit orang percaya yang bergumul juga. Ada situasi dan kondisi seperti kesakitan, kematian, kekurangan, kemiskinan, kelaparan, pengangguran, ketidakadilan yang terkadang membuat orang beriman bertanya mengapa hidup ini tidak lebih baik dibanding orang yang tidak beriman?

Pemahaman yang benar tentang Allah dan kehendakNya melalui kebenaran firmanNya sangat diperlukan untuk menjawab pertanyaan penting ini. Kita harus kembali kepada Alkitab sebagai pedoman hidup orang Kristen.

Pembahasan topik ini akan didasarkan pada Mazmur 73 karena beberapa alasan. Pertama, Mazmur adalah salah satu kitab yang paling dikenal tetapi tidak mudah untuk dipelajari karena karakteristik sastranya. Kedua, Mazmur memberikan kesaksian tentang hubungan yang penuh semangat antara Allah dengan umatNya. Ketiga, Mazmur menuntut respon total dari pembacanya. Bentuk sastra puisi dari Mazmur

${ }^{1}$ Robert L. Deffinbaugh, "Psalm 73: The Suffering of the Righteous and the Success of Sinners," dalam A Psalm for All Seasons: Studies in the Book of Psalms, online: http://www.bible.org.

${ }^{2}$ Ibid. membuatnya mampu berbicara kepada manusia seutuhnya lebih daripada prosa. Keempat, secara khusus Mazmur 73 menyaksikan tentang pengakuan yang jujur dari seorang Israel yang setia dan saleh mengenai perjuangannya sendiri dengan masalah penderitaan orang benar dan kemakmuran orang fasik.

\section{Metode dan Prosedur}

Metode yang digunakan dalam penelitian ini adalah metode kualitatif kajian biblika murni. Penelitian teks akan dilakukan dalam empat pendekatan.

Pertama, penerjemahan ulang teks Mazmur 73 dari teks Ibraninya. Hasil terjemahan secara literal akan digunakan sebagai dasar penafsiran dengan membandingkan terjemahan yang lain. Bentuk sastra mazmur juga akan dianalisis untuk menentukan jenis mazmur dan struktur teksnya.

Kedua, penafsiran akan dilakukan dengan menerapkan teori tafsir literal-gramatikalhistorikal-kontekstual. ${ }^{3}$ Arti normal suatu kata, hubungan gramatikal, latar belakang sejarah dan konteks dari suatu kata yang diselidiki akan dipertimbangkan secara bersama-sama dalam menafsirkan suatu kata atau ayat.

Ketiga, penggalian ayat-ayat Alkitab akan dilakukan secara eksegesis. Atas dasar itu, penggunaan teks Ibrani Alkitab dengan berbagai kebenaran gramatikalnya akan menjadi kegiatan rutin dalam sepanjang pembahasan.

Keempat, tinjauan literatur juga akan dilakukan dengan menggali dan mengkaji bukubuku dan artikel-artikel teologi yang tersedia.

\section{Bentuk dan Struktur Sastra}

\section{Bentuk Sastra}

Ada keragaman pendapat di kalangan para sarjana biblika mengenai bentuk sastra mazmur ini. Setidaknya ada tujuh usulan untuk bentuk sastra Mazmur 73, yaitu: mazmur hikmat, nyanyian ucapan syukur, nyanyian ratapan,

${ }^{3}$ Saparman, Belajar Alkitab: Cara $\mathcal{E}$ Contoh (Yogyakarta: STII Press, 2007), 89-122; Paul Enns, The Moody Handbook of Theology, pen. RahmiatiTanudjaja (Malang: Literatur SAAT, 2003), 213-214. 
nyanyian keyakinan, mazmur raja, dan pernyataan dari tempat suci. ${ }^{4} \mathrm{Di}$ antara semua usulan ini, genre sebagai mazmur hikmat dan nyanyian ucapan syukur individu adalah yang paling luas disebutkan. ${ }^{5}$

Beberapa sarjana biblika yang mendukung bentuk mazmur hikmat adalah Gunkel, Jacquet, Kraus, Westermann, Anderson, Luyten, Eissfeldt, Whybray, dan VanGemeren. Sedangkan Mowinckel, Schmidt, dan Weiser lebih menekankan kepada bentuk nyanyian ucapan syukur. ${ }^{6}$ Pada umumnya, para sarjana yang memegang pendapat bahwa Mazmur 73 adalah mazmur hikmat menyimpulkan mazmur ini adalah sebuah Problemgedichte, dimana pemazmur sedang bergumul dengan masalah tentang mengapa orang benar harus menderita. ${ }^{\text {? }}$ Sedangkan para ahli yang memegang pendapat bahwa Mazmur 73 adalah nyanyian ucapan syukur menyimpulkan bahwa pemazmur tidak lagi menderita, tetapi mengucap syukur kepada Tuhan karena ia telah ditolong atau mendapatkan solusi yang memuaskan sebagai gantinya. ${ }^{8}$

Menanggapi perbedaan tersebut, McCann mengusulkan untuk tidak terlalu memperhatikan jenis mazmurnya melainkan individunya. ${ }^{9}$ Apa yang diusulkan oleh McCann merupakan salah satu pertimbangan yang baik. Tetapi seperti ditulis oleh LaSor bahwa antara mazmur hikmat dan mazmur ucapan syukur pribadi hampir tidak mungkin dibedakan karena dalam nyanyian syukur diberi kesempatan bagi kesaksian pribadi

${ }^{4}$ Lihat J. Clinton McCann, Jr., "Psalm 73: A Microcosm of Old Testament Theology," dalam The Listening Heart: Essays in Wisdom and the Psalms in Honor of Roland E. Murphy, peny. K.G. Hogland, E.F. Huwiler, J.T. Glass, R.W. Lee, JSOTSup 58 (Sheffield: JSOT, 1987), 247 dan Marvin E. Tate, Psalms 51-100, Word Biblical Commentary (Dallas: Word Books, 1990), 20:233.

${ }^{5}$ Demikian juga kesimpulan McCann dan Tate.

${ }^{6}$ Selidiki Tate, Psalms 51-100, Word Biblical Commentary, 233; McCann, Jr., "Psalm 73: A Microcosm of Old Testament Theology," 47-48; James L. Crenshaw, The Psalms: An Introduction (Grand Rapids: William B. Eerdmans Publishing, 2001), 87-95.

${ }^{7}$ McCann, Jr., "Psalm 73: A Microcosm of Old Testament Theology," dalam The Listening Heart: Essays in Wisdom and the Psalms in Honor of Roland E. Murphy, 247.

${ }^{8}$ Ibid.

${ }^{9}$ Ibid., 249. tentang bimbingan Allah dan himbauan pribadi. ${ }^{10}$ Itu berarti dalam mazmur hikmat bisa juga terdapat unsur ucapan syukur di dalamnya, sehingga Mazmur 73 masih tetap dapat dikelompokkan ke dalam genre mazmur hikmat. Selanjutnya Mazmur 73 dapat dimasukkan ke dalam kelompok mazmur hikmat dengan beberapa alasan berikut ini. ${ }^{11}$

Pertama, mazmur tersebut memiliki maksud jelas untuk mengajar dengan menggumuli masalah kemakmuran orang fasik. Asaf bergumul dengan kenyataan bahwa orang fasik sepertinya hidup dalam kemakmuran (73:4-12). Kedua, mengandung tema khas dari sastra hikmat yaitu pertentangan antara yang baik dan jahat atau antara orang benar dan orang fasik. Keadaan Asaf yang menggambarkan orang benar (73:14) dipertentangkan dengan keadaan orang fasik (73:4-12). Ketiga, adanya tema hikmat seperti realitas dan kepastian akan balas jasa atau ganti rugi dan keadilan yang berkenaan dengan pemberian hukuman yang setimpal. Asaf melakukan refleksi atas ketidakadilan hidup dan bergumul dalam membuat pilihan yang benar, sampai dia masuk ke dalam tempat kudus Allah dan memperoleh perspektif yang baru. Dia mendapatkan penghiburan ketika memikirkan akhir hidup orang fasik (73:18-20) yang kontras dengan kemuliaan orang benar di masa datang (73:21-26). Keempat, adanya kosa kata hikmat

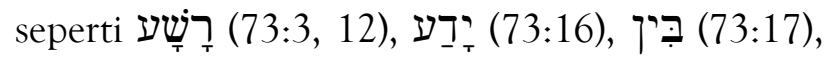

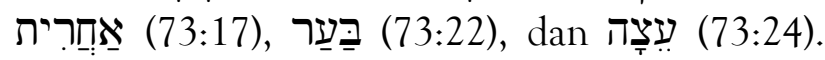
Kelima, adanya penekanan dari isi mazmur tentang dua jalan yaitu hidup dan mati $(73: 18$ 27). Jadi dapat disimpulkan bahwa bentuk sastra Mazmur 73 adalah mazmur hikmat.

${ }^{10}$ W. S. LaSor, D. A. Hubbard, dan F. W. Bush, Pengantar Perjanjian Lama 2: Sastra dan Nubuat (Jakarta: BPK Gunung Mulia, 2005), 60. Contoh kasus seperti ini dapat dilihat dalam Mazmur 37, 73, dan 78.

${ }^{11}$ Uraian tentang karakteristik mazmur hikmat dapat diselidiki dalam buku berikut ini: LaSor, Pengantar Perjanjian Lama, 2:58; Roland E. Murphy, Old Testament Reading Guide: Introduction to the Wisdom Literature of the Old Testament (Collegeville: The Liturgical Press, 1965), 41; Crenshaw, The Psalms: An Introduction, 89; Allen P. Ross, A Commentary on The Psalms: Volume 1:1-41 (Grand Rapids: Kregel Publications, 2011), 141-145; R. B. Y. Scott, The Way of Wisdom in the Old Testament (New York: MacMillan, 1971), 121. 


\section{Struktur Sastra}

Ada banyak usulan tentang struktur Mazmur 73. Tate mencatat setidaknya ada 37 pola sastra yang telah diusulkan. ${ }^{12}$ Ada yang membaginya menjadi 2 bagian, 3 bagian, 7 bagian, maupun 8 bagian. ${ }^{13}$ Keragaman pembagian struktur mazmur ini disebabkan karena variasi dalam dasar pembagian yang digunakan oleh para sarjana biblika. Ada yang membaginya berdasarkan isi atau tema dan ada yang berdasarkan analisa gaya bahasa. ${ }^{14}$

Alangkah lebih baik bila membagi mazmur ini ke dalam 3 bagian utama berdasarkan tanda struktur melalui kemunculan partikel $\mathrm{J}$ ('ak) di setiap bagiannya, yaitu: ayat 1-12, 13-17, dan 18-28. Pembagian ini menguatkan kesimpulan bahwa pemazmur telah mengalami tranformasi perspektif yang luar biasa. Pembagian ini juga menghasilkan suatu simetri yang menyoroti pembalikan perspektif pemazmur. Bagian pusat (ayat 13-17) bertindak sebagai titik balik pergumulan pemazmur.

Meskipun partikel א ('ak) mempunyai peran yang penting dalam pembagian mazmur

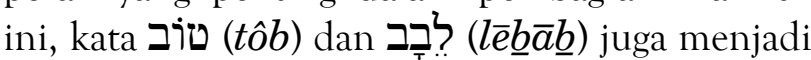
kata yang penting. Kata טֹ (tôb) yang diterjemahkan dengan "baik" muncul 2 kali pada tempat yang sangat krusial, yaitu di awal dan di akhir mazmur ini. ${ }^{15}$ Kemunculan kata ini di awal menekankan kepada keyakinan awal pemazmur yang merupakan kesimpulan perkara dan dasar dari pergumulannya. Adapun kemunculan di akhir pasal menekankan pada kesimpulan iman pemazmur setelah melewati pergumulannya.

${ }^{12}$ Tate, Psalms 51-100, 232.

${ }^{13}$ Keil-Delitzsch, Briggs, Kidner, Ross, membagi ke dalam 2 bagian. McCann 3 bagian, VanGemeren dan Crenshaw 7 bagian, dan Tate 8 bagian.

${ }^{14}$ Crenshaw, Ross dan VanGemeran membagi mazmur ini berdasarkan isi atau tema-tema yang ada di dalamnya. Sedangkan Tate dan McCann membaginya berdasarkan analisa gaya bahasa.

${ }^{15}$ Beberapa sarjana biblika seperti Crenshaw, VanGemeren, Tate, dan Deffinbaugh berpendapat bahwa kebaikan Allah merupakan salah satu tema dalam Mazmur 73 karena kemunculan kata "baik" di awal dan akhir mazmur yang menyatakan prasuposisi iman dan kesimpulan iman pemazmur.
Kemudian kata "hati" (ברָָ menjadikata kunci dalam mazmur ini, ${ }^{16}$ yang memimpin Buber untuk menyebutnya sebagai suatu "meditasi hati." 17 Kata ini muncul sebanyak 6 kali $(73: 1,7,13,21,26)$ dan merupakan akar permasalahan dari pergumulan pemazmur tentang kemakmuran orang fasik. Kata "hati" ditemukan dalam ketiga bagian struktur Mazmur 73. Berikut ini adalah ketiga bagian itu.

\section{Bagian Pertama}

Bagian pertama adalah ayat 1-12. Bagian ini diawali dengan partikelFא ('ak) yang menegaskan iman pemazmur bahwa Allah adalah baik. Gagasan utama yang disampaikan pada bagian ini adalah permasalahan orang benar tentang kemakmuran orang fasik. Gagasan ini dikembangkan lebih lanjut dengan membandingkan keadaan orang benar yang kritis (73:1-3) dengan keadaan orang fasik yang sepertinya makmur (73:4-12).

Permasalahan ini diawali dengan keyakinan iman orang benar tentang kebaikan Allah (73:1) dan berlanjut dengan pengakuan secara terbuka mengenai kondisi imannya yang kritis (73:2). Kontras antara keyakinan iman dengan keadaan imannya yang kritis diperkenalkan melalui kata בֵַַַני (waăni) yang artinya "tetapi aku." Keadaan itu disebabkan karena keirihatian terhadap kemakmuran orang fasik (73:3). Alasan dari keirihatian diperkenalkan dengan kata sambung 'כ $(k \hat{\imath})$, yaitu karena kesejahteraan, kejahatan, dan kepopuleran orang fasik (73:4-12).

\section{Bagian Kedua}

Bagian kedua adalah ayat 13-17. Bagian ini diawali juga dengan partikel $\bar{\aleph}\left({ }^{\prime} a k\right)$ yang menjelaskan reaksi orang benar terhadap kemakmuran orang fasik. Gagasan utamanya adalah mengenai respon orang benar yang bergumul tentang kemakmuran orang fasik.

${ }^{16}$ Crenshaw, The Psalms: An Introduction, 115-117.

${ }^{17}$ Martin Buber, "The Heart Determines: Psalm 73," dalam Issues in Religion and Theology 4: Theodicy in the Old Testament, peny. James L. Crenshaw (Philadelphia: Fortress, 1968), 109-118. 
Pada ayat 13-14 digambarkan tentang puncak kekhawatiran pemazmur dari observasinya terhadap hidup orang fasik. Dasar permasalahan orang benar yang sesungguhnya adalah hatinya (73:13). Ayat 15 merupakan ungkapan jujur pemazmur kepada Allah tentang suasana hatinya yang membawa kepada penyerahan kepada Allah (73:17).

Bagian ini merupakan titik balik bagi perubahan perspektif orang benar. Pembalikan diawali dari ayat 15 dan puncaknya adalah ayat 17. Jadi pembalikan perspektif pemazmur merupakan suatu proses dan bukanlah titik tertentu pada satu saat tertentu.

\section{Bagian Ketiga}

Bagian ketiga adalah ayat 18-28. Sekali lagi bagian ini diawali dengan partikel 7 ('ak) yang menegaskan jawaban Allah kepada orang benar melalui pembalikan perspektifnya. Gagasan utama bagian ini adalah mengenai jawaban Allah atas akhir hidup orang fasik, orang benar dan makna dari kebaikan Allah. Akhirnya,

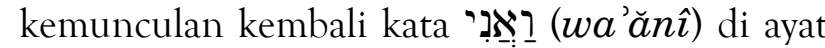
terakhir menegaskan komitmen orang benar kepada Allah. Kata ini juga menegaskan secara kontras dengan ayat 2 tentang keadaan orang benar secara fisik pada masa kini dan keyakinan imannya akan kebaikan Allah yang dinyatakan melalui kedekatan Allah kepada pemazmur.

Pada ayat 18-20 akhir hidup orang fasik digambarkan secara buruk, sedangkan ayat 21-28 menggambarkan keadaan orang benar yang makmur dan kontras dengan keadaannya pada bagian pertama. Perspektif orang benar tentang kebaikan Allah juga diperbarui di ayat 28. Selanjutnya diuraikan analisis dari Mazmur 73.

\section{Permasalahan Orang Benar tentang Kemakmuran Orang Fasik (Mzm. 73:1-12)}

Permasalahan yang dialami oleh pemazmur berawal dari keyakinannya akan kebaikan Allah. Keyakinannya itu diperhadapkan dengan keadaan orang fasik yang makmur. Disinilah letak pergulatan iman pemazmur yang sangat berat.

\section{Keadaan Orang Benar yang Kritis (Mzm. 73:1-3)}

Ayat 1-3 membahas tentang kondisi pemazmur yang sedang bergumul dengan kemakmuran orang fasik. Kemakmuran orang fasik telah membuat keyakinan imannya akan kebaikan Allah terguncang dan ia berada pada keadaan yang kritis. Pergumulan pemazmur dimulai dari keyakinan awalnya tentang pribadi Allah di satu sisi dan di sisi lain pengalamannya secara pribadi ketika melihat fakta kehidupan yang berbeda disekitarnya. Fakta kehidupan tentang orang fasik sepertinya bertentangan dengan apa yang diyakininya selama ini.

\section{Keyakinan Awal akan Kebaikan Allah (73:1)}

Asaf memulai mazmur ini dengan sebuah keyakinan awal bahwa "Allah adalah baik bagi Israel, bagi mereka yang murni dalam hati." Keyakinannya dinyatakan dengan penggunaan kata "sesungguhnya" dari kata Ibrani $\overline{7} \underline{\text { ( }}(' a \underline{k})$ yang berfungsi untuk menegaskan sesuatu. ${ }^{18}$ Kata tersebut menunjukkan keyakinan pemazmur bahwa Allah adalah baik. Meskipun sepertinya Allah tidak memperhatikan Asaf, tetapi dia belajar dari pengalamannya bahwa Allah adalah baik dan inilah yang diyakininya.

Frase "Allah adalah baik" menyatakan kesempurnaan Allah. Dalam konteks religius, kata "baik" mempunyai dua pengertian, yaitu sebagai konsep abstrak dan manifestasi konkritnya. Sebagai sebuah konsep abstrak, kata ini menunjuk kepada Allah yang diidentifikasikan sebagai baik. Sedangkan manifestasi konkritnya dihubungkan dengan tindakan Allah yang menyelamatkan umatNya. ${ }^{19}$ Pemazmur meyakini bahwa Allah adalah baik kepada dia dan umat Israel. Selanjutnya frase "bagi yang murni hati" lebih menekankan kepada motif yang ada dalam hati. VanGemeren menjelaskan bahwa yang dimaksud dengan murni bukanlah kesempur-

${ }^{18}$ Ronald J. Williams, Hebrew Syntax: An Outline (Toronto: University of Toronto Press, 1976), 65.

${ }^{19}$ I. Hover-Johag, "טרב," dalam Theological Dictionary of the Old Testament, G. Johannes Botterweck dan Helmer Ringgren, pen. David. E. Green (Grand Rapids: William B. Eerdmans Publishing Company, 1986), 5:314-315. 
naan melainkan hidup dalam kesetiaan kepada Allah dalam tutur kata dan tindakan serta menunjukkan motif yang murni. ${ }^{20}$ Kemurnian ini juga bukan sekedar pikiran yang bersih, tetapi merupakan komitmen total kepada Allah. ${ }^{21}$

Adapun kemunculan kata "hati" sebanyak 6 kali $(73: 1,7,13,21,26)$ menegaskan bahwa hati merupakan masalah kunci dari pemazmur. Crenshaw melihat pengulangan ini sebagai kata kunci atau konsep kunci Mazmur 73. ${ }^{22}$ Itu sebabnya Martin Buber menyebut mazmur ini sebagai "meditasi hati." 23 Jadi, apa yang dialami Asaf sebenarnya adalah masalah hati yang nanti akan dikembangkan dalam ayat-ayat selanjutnya.

\section{Kehidupan Rohani yang Genting (73:2)}

Asaf mulai beralih dari keyakinannya akan kebaikan Allah kepada fakta-fakta yang membuat kehidupan rohaninya genting. Gambaran secara panjang lebar tentang pergumulannya diawali dengan sebuah kata sambung I $(w a)$. Konjungsi ini muncul empat kali $(73: 2,22,23,28)$ dan setiap kemunculannya diikuti dengan pengakuan pemazmur atas kesalahannya $(73: 2,22)$ serta menekankan apa yang Allah telah lakukan bagi dia $(73: 23,28) .{ }^{24}$ Kata sambung ? $(w a)$ pada ayat 2 menyatakan kontras dengan keyakinan iman Asaf di ayat 1 serta mengawali penjelasan tentang situasi rohani yang genting (73:2), kecemburuan kepada orang fasik (73:3), alasan cemburu (73:412), dan reaksinya terhadap kemakmuran orang fasik (73:13-17). Kemudian kata sambung ? (wa) diikuti dengan kata ganti orang pertama tunggal אַנְי ('ănî) yang menunjukkan perubahan pokok pembicaraan dari pribadi Allah yang baik kepada

${ }^{20}$ Willem A. VanGemeren, "Psalms," dalam The Expositor's Bible Commentary, (Grand Rapids: Zondervan Publishing House, 1991), peny. um. Frank E. Gaebelein, 5:476.

${ }^{21}$ Derek Kidner, Psalms 73-150: A Commentary on Books IIL-V of the Psalms, Tyndal Old Testament Commentaries (Downers Grove: Inter-Varsity Press, 1975), 259.

${ }^{22}$ James L. Crenshaw, The Psalms: An Introduction (Grand Rapids: William B. Eerdmans Publishing Company, 2001), 115-117.

${ }^{23}$ Buber, "The Heart Determines: Psalm 73," 111.

${ }^{24}$ VanGemeren, "Psalms," dalam The Expositor's Bible Commentary, 5:477. pemazmur yang bergumul dengan kemakmuran orang fasik.

Asaf menggambarkan keadaan pikiran dan hatinya yang genting dengan frase puitis yang sejajar yaitu "kakiku hampir tersandung, langkahku nyaris tergelincir." Kedua frase tersebut menggambarkan keadaan pikiran dan hati pemazmur yang tidak stabil. Deffinbaugh melihat masalah Asaf ini sebagai masalah teologi karena berhubungan dengan perjanjian Allah yang semula untuk memberkati orang benar dan mengutuk orang fasik (Ul. 28-30). ${ }^{25}$ Pengharapan inilah yang membuat pemazmur hampir kehilangan pegangannya. Keyakinan imannya akan kebaikan Allah telah digoncangkan oleh pikiran dan perasaan yang dipenuhi dengan kecemburuan terhadap kemakmuran orang fasik.

\section{Kecemburuan terhadap Orang Fasik (73:3)}

Kata sambung (ִִּ $(k \hat{\imath})$ menjelaskan "alasan"26 yang membuat pemazmur berada dalam kehidupan rohani yang genting. Kecemburuan adalah masalah utama yang membuat Asaf berada pada situasi iman yang kritis. Kata

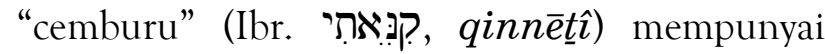
dua pengertian yaitu: pertama, suatu pengertian tentang hak atas suatu obyek yang dalam bahasa Inggris sering diterjemahkan dengan kata envy. Kedua, suatu klaim atau tuntutan atas seseorang yang diterjemahkan dalam bahasa Inggris sebagai jealousy. ${ }^{27}$ Pengertian dari kata "cemburu" dalam ayat 3 adalah envy. Jadi, Asaf cemburu karena ia merasa lebih berhak untuk mendapatkan kemakmuran yang dialami oleh orang fasik. Oleh sebab itu Deffinbaugh berpendapat bahwa salah satu yang menyebabkan perspektifnya menyimpang adalah Asaf mengganggap dirinya

\footnotetext{
${ }^{25}$ Deffinbaugh, "Psalm 73: The Suffering of the Righteous and the Success of Sinners," online: http://www.bible.org.

${ }^{26}$ Bill T. Arnold dan John H. Choi, A Guide to Biblical Hebrew Syntax: Second Edition, (Cambridge: Cambridge University Press, 2018), 160-166.

${ }^{27}$ E. Reuter,"קנא," dalam Theological Dictionary of the Old Testament, peny. G. Johannes Botterweck, Helmer Ringgren, dan Heinz-Josef Fabry, pen. David E. Green (Grand Rapids: William B. Eerdmans Publishing Company, 1986), 13:49-53.
} 
benar, lebih baik, dan lebih pantas mendapatkan berkat Allah. ${ }^{28}$

Pemazmur cemburu kepada orang fasik yang disebutnya sebagai "pembual-pembual." Istilah tersebut berasal dari kata Ibrani הiֹלְיִ (hŏlelîm) yang berbentuk Qal sehingga lebih tepat diterjemahkan sebagai "memperdayakan atau menipu." 29 Kata ini menunjuk kepada orang-orang fasik yang memperdaya dengan kemakmuran mereka. Pengertian ini selaras dengan uraian dalam ayat-ayat selanjutnya yang menjelaskan bahwa kemakmuran orang fasik hanyalah sementara dan membawa kepada kehancuran (73:18-20). Kecemburuan Asaf disebabkan karena dia melihat kemakmuran orang fasik. Kata "melihat" (Ibr. אֶר " 'ere'eh) jika dihubungkan dengan kata "cemburu" (Ibr.

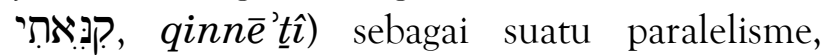
mempunyai makna yang bukan sekedar melihat tetapi "mendambakan." ${ }^{30}$ Pemazmur mendambakan kemakmuran yang dialami oleh orang fasik. Keinginan ini berkaitan dengan masalah hati dan semakin mempertegas akar permasalahan pemazmur yaitu hati.

Apa yang didambakan oleh pemazmur adalah kemakmuran (Ibr. שִׁלְ, selôm) orang fasik. G. Lloyd Carr meringkaskan konsep sālôm bagi orang Israel sebagai berikut:

shālôm is the result of God's activity in covenant $\left(b^{e} r \hat{t} t\right)$, and is the result of righteousness (Isa. 32:17). In nearly two-thirds of its occurrences, shālôm describes the state of fulfilment which is the result of God's presence. This is specifically indicated in those references to the "covenant of peace" ( $b^{e}$ rît shālôm, Num. 25:12; Isa. 54:10; Ezek. 34:25; Mal. 2:5) with his chosen representatives, the Aaronic priests and the Davidic monarchs. 31

Asaf tentu memahami konsep tentang $s \bar{a} l o ̂ m$ tersebut dan inilah yang membingungkan

\footnotetext{
${ }^{28}$ Robert L. Deffinbaugh, "The Goodness of God," dalam Let Me See Thy Glory - A Study of the Attributes of God, online: http://www.bible.org.

${ }^{29}$ William L. Holladay, A Concise Hebrew and Aramaic Lexicon (Grand Rapids: William B. Eerdmans Publishing, 1988), 81.

${ }^{30}$ Tate, Psalms 51-100, 228.

31 G. Lloyd Carr, "שָׁלוֹ" dalam Theological Wordbook of the Old Testament, 2:931.
}

dia ketika melihat kemakmuran orang fasik. Dari sudut pandangnya, berkat perjanjian Allah sedang dituangkan atas orang fasik, selagi hukuman ilahi ada begitu banyak pada orang benar (73:14). Allah sepertinya telah memutar perjanjianNya terbalik. Oleh sebab itu tidak mengherankan jika Asaf bingung dan cemburu.

\section{Keadaan Orang Fasik yang Makmur (Mzm. 73:4-12)}

Kemakmuran orang fasik yang menyebabkan pemazmur cemburu dan berada pada situasi kritis dari imannya dijelaskan dalam ayat 4-12. Ada tiga gambaran tentang keadaan orang fasik yang makmur.

\section{Kesejahteraan Orang Fasik (73:4-5)}

Ayat 4-5 memberikan gambaran tentang kemakmuran atau sālôm dari orang fasik yang sangat materialistik.Kesejahteraan orang fasik digambarkan dalam empat ungkapan. Pertama, "tidak ada kesakitan pada kematian mereka" (73:4a). Kata "kesakitan" (Ibr. חַרְצִבּרוֹת ", harșubôt) mempunyai arti metafora." ${ }^{32}$ Kata ini menggambarkan kondisi kematian orang fasik yang tanpa kesakitan atau kesengsaraan. Artinya kesejahteraan orang fasik terlihat sampai kepada kematian mereka yang mudah tanpa harus mengalami kesakitan.

Kedua, "gemuk tubuh mereka" (73:4b). Kesejahteraan orang fasik secara positif digambarkan melalui tubuh yang gemuk. Istilah "gemuk" merupakan gambaran kuno dari kemakmuran dalam hal kesehatan dan menikmati suatu kelimpahan. ${ }^{33}$ Kondisi ini menunjukkan bahwa mereka adalah orang-orang yang kaya. Mereka memperhatikan tubuh mereka dengan kekayaannya sehingga berada pada kondisi tubuh yang optimal.

Ketiga, "tidak mengalami kesusahan manusia” (73:5a). Istilah "kesusahan manusia" berhubungan dengan sisi gelap dari seorang pekerja yang menyedihkan dan tidak terpenuhi

\footnotetext{
${ }^{32}$ Holladay, A Concise Hebrew and Aramaic Lexicon,
} 118. 
dari pekerjaan. Sedangkan kata bendanya berhubungan dengan faktor-faktor yang tidak menyenangkan dari pekerjaan dan bekerja keras. ${ }^{34}$ Jadi kesejahteraan orang fasik digambarkan sebagai keadaan yang bebas dari kesusahan dalam bekerja untuk memenuhi kebutuhan.

Keempat, "tidak ditulahi seperti orang lain" (73:5b). Kesejahteraan orang fasik digambarkan dengan kebebasan mereka dari penderitaan atau penyakit yang berasal dari Allah. Kata "tidak ditulahi" sejajar dengan kata "tidak ada kesusahan" yang mempertegas gambaran tentang kesejahteraan orang fasik yang bebas dari masalah manusia sehari-hari. Keadaan orang fasik ini kontras dengan keadaan pemazmur yang mengalami hajaran dan hukuman sepanjang hari (73:14). Jadi pemazmur sedang membandingkan hidup orang fasik dengan hidupnya sendiri yang dipenuhi dengan hukuman dari Allah.

Akhirnya dapat disimpulkan bahwa Asaf menjadi cemburu kepada orang-orang fasik karena ia melihat kesejahteraan atau sālôm mereka. Kesejahteraan itu dilukiskan sebagai bebas dari penyakit, memiliki kondisi tubuh yang optimal, bebas dari bekerja keras dan dari hajaran Allah. Situasi yang membuat pemazmur bingung dan tergoncang imannya adalah bahwa orang fasik sedang mengalami sālôm yang ia percayai seharusnya dialami oleh orang benar.

\section{Kejahatan Orang Fasik (73:6-9)}

Asaf semakin disusahkan dengan kelakuan mereka yang jahat. Orang fasik sudah menikmati hidup duniawi secara berkelimpahan namun hidup mereka semakin semena-mena. Setidaknya ada tiga kejahatan orang fasik yang diamati pemazmur.

Pertama, bangga terhadap kesombongan dan

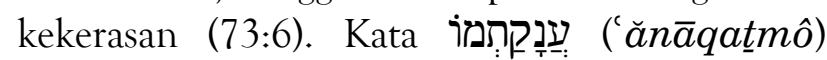

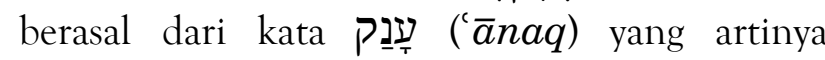
"bertindak sebagai kalung." ${ }^{35}$ Kalung merupakan perhiasan yang dipakai di leher oleh laki-laki seperti pada wanita di Timur Dekat Kuno,

\footnotetext{
${ }^{34}$ Ronald B. Allen, "עָדָלָל dalam Theological Wordbook, 2:675.

${ }^{35}$ Holladay, A Concise Hebrew and Aramaic Lexicon,
}

sebagai suatu bukti kekayaan, kekuasaan dan status atau gengsi seseorang (Kej. 41:42; Dan. 5:7). ${ }^{36}$ Jadi orang fasik menjadikan kesombongan sebagai kebanggaannya, bahkan menganggapnya seperti kekayaan dan kekuasaannya. Kemudian

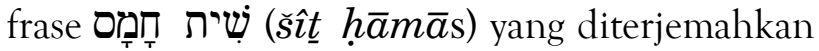
dengan "pakaian kekerasan" menjelaskan bahwa kesombongan mereka memimpin kepada kekerasan terhadap orang lain. Kekerasan ini menjadi kebiasaan dalam hidup mereka dan merupakan suatu ciri yang ditunjukkannya kepada orang lain sebagai pakaian. ${ }^{37}$

Kedua, mata dan hati yang digunakan untuk kejahatan (73:7). Mata dan hati orang fasik digunakan sebagai alat kejahatan yang tidak terbatas. ${ }^{38}$ Ayat 7a berbunyi "Mata mereka keluar karena kegemukan.” Mata menggambarkan persepsi orang fasik yang menyimpang karena kondisi kesehatan jasmani. Adapun ayat $7 \mathrm{~b}$ berbunyi "imajinasi-imajinasi hati mereka meluap." Ada paralelisme yang intensif antara "persepsi" dengan "imajinasi hati" dan "keluar" dengan "meluap." Jadi hati orang fasik penuh dengan imajinasi yang jahat karena kemakmuran mereka.

Ketiga, tutur kata yang penuh dengan kejahatan, penindasan, dan kesombongan (73:89). Oleh karena mata dan hati orang fasik dipenuhi dengan persepsi dan imajinasi yang jahat, maka mereka dengan mudahnya mengeluarkan kata-kata ejekan dan penindasan. Mereka mengeluarkan perkataan itu dari tempat tinggi. Orang fasik mengejek, berkata-kata jahat dan penindasan dengan angkuhnya, seolah-olah mereka berbicara dari surga. Briggs menjelaskan bahwa orang fasik dengan bangganya berkatakata dan melakukan kejahatan setiap hari. ${ }^{39}$ Bahkan lebih jauh lagi mereka menetapkan mulutnya di langit. Beberapa sarjana biblika mengartikan frase "menetapkan mulut di langit"

${ }^{36}$ Charles Augustus Briggs dan Emilie Grace Briggs, A Critical and Exegetical Commentary on the Book of Psalms, The International Critical Commentary (Edinburgh: T \& T. Clark, 1906), 143; bnd. VanGemeren, "Psalms," dalam The Expositor's Bible Commentary, 5:478.

${ }^{37}$ Ibid., 143.

${ }^{38}$ Allen P. Ross, "Psalms," dalam The Bible Knowledge Commentary, peny. John F. Walvoord dan Roy B. Zuck, (Wheaton: Victor Books, 1985), 1:847.

${ }^{39}$ Briggs, A Critical and Exegetical Commentary, 143. 
dengan penentangan terhadap Allah bahkan menghujat Dia. ${ }^{40}$ Jadi orang fasik mengumbar perkataan mereka yang penuh dengan ejekan, kejahatan, dan penindasan dengan semena-mena tanpa ada rasa hormat kepada Allah. Bahkan mereka mengeluarkan ejekan, kejahatan, dan penindasan terhadap orang benar.

Ide dari frase "menetapkan mulut di langit" paralel dengan frase "lidah mereka membual di

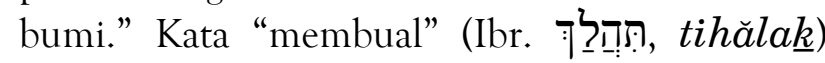
menyatakan "sikap yang jahat dari lidah"41 Artinya lidah orang fasik digunakan secara leluasa untuk berkata-kata penindasan di bumi (bnd. 73:8). Jika kedua frase ini dipertimbangkan secara bersama-sama, maka ayat 9 menggambarkan orang fasik yang tutur katanya penuh dengan kesombongan. Mereka menggunakan mulutnya secara leluasa tanpa takut kepada Allah dan tanpa berperasaan kepada orang lain.

\section{Kepopuleran Orang Fasik (73:10-12)}

Orang fasik bukan saja kelihatan makmur (73:4-5) dan berbuat jahat (73:6-9), tetapi mereka juga populer. Banyak orang berbalik mengikuti mereka, baik dalam prinsip maupun prakteknya

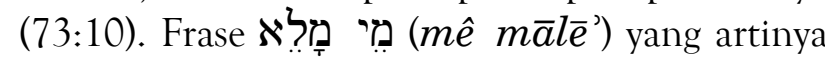
"air yang berlimpah" merupakan sebuah metafora bagi kemakmuran orang-orang fasik. ${ }^{42}$ Beberapa orang dari umat Israel yang berbalik dari Allah telah ditarik oleh kemakmuran dan kejahatan orang fasik tanpa memikirkan akibat dari gaya hidup makmur mereka.

Para pengikut orang fasikjuga mengeluarkan kata-kata yang menentang Allah (73:11). Mereka mulai berkata-kata seperti orang fasik yang tidak takut akan Allah. Menurut VanGemeren pertanyaan retoris dalam ayat 11 menunjukkan

${ }^{40}$ F. Delitzsch, Psalms, Commentary on the Old Testament in Ten Volumes, pen. James Martin (Grand Rapids: William B. Eerdmans Publishing Company, 1955), 5:314; Briggs, A Critical and Exegetical Commentary, 144.

${ }^{41}$ Francis Brown, S.R. Driver, and Charles A. Briggs, A Hebrew and English Lexicon of the Old Testament (Oxford: Clarendon Press, 1906), 229.

${ }^{42}$ Arti frase ini cukup sulit. Beberapa sarjana seperti Cohen, Gunkel, dan Kraus menerjemahkan sebagai “meminum kata-kata mereka." Lihat Tate, Psalms 51-100, 229. bagaimana para pengikut orang fasik tidak menolak eksistensi Allah tetapi membatasi Dia dalam pengetahuan dan hikmatNya. ${ }^{43}$ Dalam perspektif mereka, Allah hanya perhatian dengan agama, kesalehan, perbuatan baik dan tidak peduli dengan kejahatan mereka. Oleh sebab itu, pemazmur menyimpulkan bahwa orang fasik sedang makmur tidak hanya secara materi dan fisik, tetapi juga bertumbuh secara kuantitas.

Gambaran tentang keadaan orang fasik mencapai kesimpulannya di ayat 12 . Kesimpulan pemazmur dinyatakan dalam dua hal. Pertama, hidup mereka "selalu senang." Kesejahteraan, kejahatan, dan kepopuleran mereka merupakan lukisan dari kesenangan hidup orang fasik. Masa kesenangan mereka lama. ${ }^{44}$ Briggs menanggapi ungkapan ini dengan mengatakan "mereka mempunyai hidup yang mudah dan makmur, tanpa takut akan Allah dan tanpa kekuatiran manusia, dalam kenikmatan penuh akan tubuh dan pikiran." 45 Kedua, mereka memperbesar

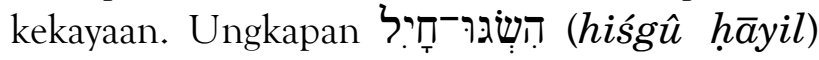
menjelaskan tentang orientasi hidup orang fasik yang senantiasa memperbesar kemakmuran diri. Oleh sebab itu Briggs mengatakan bahwa orang fasik menjadi lebih kaya dan lebih kaya lagi. ${ }^{46}$ Jadi, ayat 12 merangkum keluhan pemazmur mengenai orang fasik, yaitu mereka senang dan bertambah makmur, bahkan dalam kejahatan mereka sekalipun.

\section{Reaksi Orang Benar tentang Kemakmuran Orang Fasik (Mzm. 73:13-17)}

Setelah pemazmur mengamati cara hidup orang fasik dan hasilnya, pemazmur sampai pada puncak pergumulan yang membuatnya seperti akan mengambil keputusan yang bertentangan dengan keyakinan imannya semula. Pemazmur bergerak dari keraguannya akan nilai-nilai rohani

${ }^{43}$ VanGemeren, "Psalms," dalam The Expositor's Bible Commentary, 5:479; bnd. Briggs, A Critical and Exegetical Commentary, 144.

${ }^{44}$ Kata עוֹלד ('ôlām) bisa berarti waktu yang lama. Lihat Holladay, A Concise Hebrew and Aramaic Lexicon, 267.

${ }^{45}$ Briggs, A Critical and Exegetical Commentary, 144. 145.

${ }^{46}$ Ibid. 
yang diyakininya kepada keterbukaan hati akan Allah yang membuat dia memperhadapkan pergumulannya kepada Dia. Ini merupakan langkah awal pemazmur dalam mendapatkan jawaban yang mengubah perspektifnya tentang kebaikan Allah.

\section{Meragukan Nilai-Nilai Kerohanian (Mzm. 73:13-14)}

Pernyataan pada ayat 13 dibuka dengan kemunculan kembali partikel $\overline{7} \underline{\text { ('a }}$ ( $\underline{k}$ ) tetapi dengan penekanan yang berbeda dari ayat 1 . Ayat 13 menegaskan reaksi pemazmur terhadap observasinya tentang keadaan orang fasik yang makmur (73:4-12) dan membandingkan dengan keadaannya sendiri $(73: 1-3)$. Pernyataan dalam ayat ini kontras dengan keyakinannya dalam pembukaan mazmur. Pernyataan pemazmur ini melukiskan krisis nilai yang sedang dihadapinya.

Keraguan pemazmur tentang nilai-nilai kerohaniannya dinyatakan dalam dua pernyataan. Pertama, "sia-sia menjaga hati yang murni." Asaf merasa bahwa usahanya untuk menjaga kemurnian hati menjadi sia-sia. Kata "hati" (Ibr. לברָ mazmur ini muncul kembali di ayat 13. Menjaga hati yang murni merupakan ekspresi tentang perhatian kepada keadilan dan kebenaran (bnd. 24:4; 119:9). Kedua, "sia-sia mencuci tangan dalam ketidakbersalahan." Pencucian tangan merupakan upacara yang menandakan seseorang tidak bersalah (U1. 21:6-7; Mzm. 26:6; Mat. 27:24). Meskipun Asaf telah melakukan semuanya, tetapi setelah ia melihat kemakmuran orang fasik dan cara hidupnya, ia merasa semuanya itu seperti tidak ada faedahnya. Ditambah lagi dengan pengalamannya yang diungkapkan dalam ayat 14: "aku telah dilanggar sepanjang hari, dan teguranku [mulai] setiap pagi." Pemazmur merasa seringkali mengalami

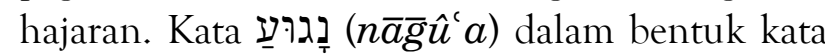

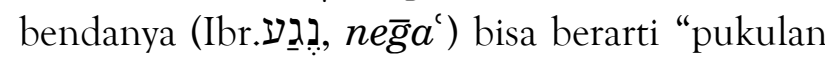
atau hajaran, penyakit atau wabah, dan tanda." ${ }^{47}$ Pengertian sebagai "penyakit atau wabah" adalah yang paling sering muncul dalam Perjanjian

\footnotetext{
${ }^{47}$ Holladay, A Concise Hebrew and Aramaic Lexicon, 619.
}

Lama (Kej. 12:17; Kel. 11:1), yaitu sekitar 76 kali. ${ }^{48}$ Kata benda נִגֵַע $\left(n e \bar{g} a^{c}\right)$ ini menunjuk kepada serangan secara fisik, atau kepada hukuman yang diberikan seorang maharaja. Biasanya Allah yang memberikan hukuman atau penyakit. Sebagian besar penggunaannya muncul dalam Imamat 13-14 dan berkenaan dengan penyakit menular seperti kusta. ${ }^{49}$ Pemazmur meragukan apa yang diyakini dan dilakukannya selama ini dan inilah puncak kekecewaannya.

\section{Membuka Diri kepada Allah (Mzm. 73:15-16)}

Keraguan pemazmur terhadap nilai-nilai kerohanian yang selama ini dipegang dan dipraktekkan hampir membawanya untuk mengikuti cara hidup orang fasik, seperti yang dilakukan oleh beberapa orang dari antara umat Israel (73:15; bnd. 73:2). Partikel hipotesis אִ ('im) di ayat 15 menunjukkan bahwa Asaf mulai berandai-andai. Dia sedang mempertimbangkan untuk mengikuti cara hidup orang fasik. Akan tetapi keputusan itu tidak jadi diambil karena ia mengingat "keturunan anak-anakmu." Pada umumnya para sarjana biblika setuju bahwa frase

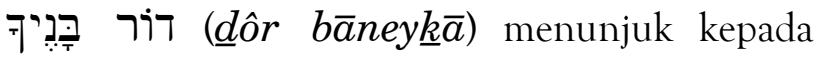
keturunan Israel atau umat Allah (bnd. Ul. 14:1; Kel. 4:22). ${ }^{50}$ Bagi Asaf, jika dia membiarkan emosi menguasainya, maka dia telah berkata-kata menentang komunitas umat Allah dan mengkhianati mereka. Pemazmur menyadari bahwa apa yang diputuskannya akan membawa pengaruh terhadap orang lain.

Keterbukaan pemazmur ini merupakan langkah penting yang mengawali proses pembalikan perspektifnya, dimana puncaknya dialami ketika ia masuk ke dalam tempat kudus

${ }^{48}$ Leonard J. Coppes, "To Touch," dalam Nelson's Expository Dictionary of the Old Testament, peny. Merril F. Unger dan William White (Nashville: Thomas Nelson Publishers, 1980), 265.

${ }^{49}$ Leonard J. Coppes, "נְגֵַ," dalam Theological Wordbook of the Old Testament, 2:551-552.

${ }^{50}$ Mitchel Dahood, The Anchor Bible: Psalms II 51 100 (Garden City, NY: Doubleday \& Company, 1968), 191; bnd. VanGemeren, "Psalms," dalam The Expositor's Bible Commentary, 5:480; Briggs, A Critical and Exegetical Commentary on the Book of Psalms, 145. 
Allah. Roland E. Murphy berpendapat bahwa sesungguhnya ayat 15 menegaskan keputusan pemazmur untuk menjadi salah satu anggota dari komunitas umat Tuhan yang setia. ${ }^{51}$ Pemazmur menyatakan komitmennya untuk tetap setia kepada generasi umat Israel. Ayat 16 semakin memperjelas keterbukaan pemazmur kepada Allahnya. Ia mengakui bahwa tidak mungkin mengikuti cara hidup orang fasik karena dengan demikian dia akan mengkhianati umatnya. Di sisi lain pemazmur juga sulit memahami jalanjalan Allah. Kesulitan yang dihadapi pemazmur pada akhirnya membawa kepada puncak dari proses pembalikan perspektifnya, yaitu "ke dalam tempat kudus Allah” (73:17).

\section{Membawa Pergumulan kepada Allah (Mzm. 73:17)}

Pemazmur membawa pergumulannya kepada Allah. Ini merupakan puncak dari proses pembalikan perspektifnya. Ada persetujuan umum bahwa ayat 17 menggambarkan sebuah pengalaman yang mewakili titik balik pemazmur terhadap pergumulannya dan juga titik balik dari mazmur ini. ${ }^{52}$ Tetapi Murphy melihat ayat 13-17 sebagai sebuah kesatuan yang berperan sebagai titik baliknya yang puncaknya adalah ayat $17 .^{53}$ Penulis melihat ayat $15-17$ menjadi rangkaian proses titik balik pemazmur. Jadi pembalikan perspektif pemazmur merupakan suatu proses yang diawali dari ayat 15 sampai puncaknya pada ayat 17 . Murphy memahami lebih lanjut ayat 17 sebagai bentuk tindak lanjut keputusan pemazmur untuk menjadi salah satu umat Tuhan yang setia dengan terus memelihara hubungan dengan Tuhan. ${ }^{54}$

Pemazmur membawa pergumulannya ke dalam tempat kudus Allah. Frase "tempat kudus

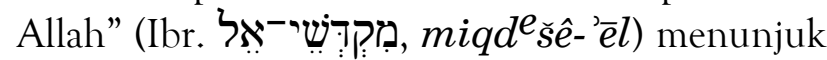
kepada bait suci beserta seluruh wilayah dan

${ }^{51}$ Roland E. Murphy, "The Listening Heart: Essays in Wisdom and the Psalms in Honor of Roland E. Murphy, O. Carm," dalam Journal for the Study of the Old Testament Supplement 58, peny. Kenneth G. Hoglund (Sheffiled: JSOT Press, 1987), 250.

${ }^{52}$ Ibid., 248.

${ }^{53}$ Ibid., 250.

${ }^{54}$ Ibid. kekudusan tempat itu karena dalam Perjanjian Lama tabut perjanjian dan bait suci merupakan simbol dari kehadiran dan pemerintahan Allah. Melalui pengalamannya dalam tempat kudus, pemazmur diubahkan perspektifnya dalam memahami kemakmuran orang fasik, hidupnya, serta keadilan dan kebaikan Allah.

\section{Jawaban bagi Orang Benar tentang Kemakmuran Orang Fasik (Mzm. 73:18-28)}

Allah mengubah perspektif Asaf yang keliru. Pemazmur dibukakan perspektifnya tentang tiga hal, yaitu: keadaan akhir orang fasik (73:18-20), keadaan orang benar (73:21-26), dan kebaikan Allah yang membawa kepada komitmen yang baru dalam hidupnya (73:27-28).

\section{Keadaan Akhir Orang Fasik yang Menyedihkan (Mzm. 73:18-20)}

Ayat 18 dibuka dengan kemunculan kembali

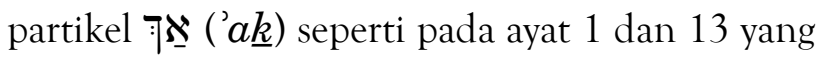
menekankan penegasan. Namun pernyataan pada ayat 18 ini menegaskan hal yang berbeda

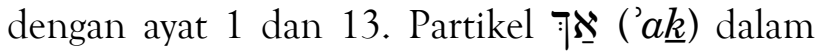
ayat 18 menegaskan keyakinan pemazmur bahwa orang fasik akan dihukum di akhir hidup mereka. ${ }^{55}$

Perspektif pertama yang dibukakan oleh Allah kepada pemazmur berkenaan dengan masa depan hidup orang fasik yang menyedihkan. Keadaan orang fasik yang menyedihkan digambarkan dalam tiga bagian. Pertama, akhir hidup orang fasik ditentukan untuk jatuh (73:18). Allah meletakkan orang fasik di tempat

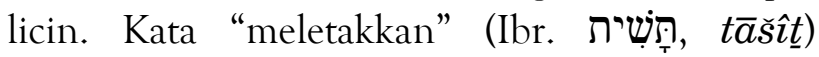
muncul di ayat 9 yang menggambarkan kesewenang-wenangan orang fasik dalam bertutur kata. Tetapi dalam ayat 18a, kata תָּשׁית

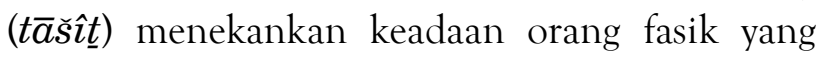
telah ditentukan oleh Allah untuk jatuh. Mereka diletakkan oleh Allah dalam kondisi yang sama seperti kondisi pemazmur di ayat 2. Tetapi perbedaannya, di ayat 2 Allah tidak mengijinkan pemazmur tergelincir ke dalam dosa sedangkan

\footnotetext{
${ }^{55}$ Dahood, The Anchor Bible: Psalms II 51-100, 192.
} 
di ayat 18a orang fasik diletakkan untuk jatuh. Keberadaan orang fasik di "tempat-tempat licin" dihubungkan secara paralel dengan keadaan "jatuh kepada tipu muslihat" (73:18b). Hal ini menjelaskan bagaimana Allah meletakkan jalan hidup orang fasik di tempat-tempat yang menipu mereka. Kemakmuran yang dibanggakan orang fasik telah menipu mereka karena melalui kemakmuran itulah hidup mereka akan jatuh.

Kedua, kehancuran orang fasik terjadi secara tiba-tiba (73:19). Waktu di mana hidup orang fasik hancur tidak disebutkan dengan jelas, tetapi Alkitab memastikan bahwa waktunya segera. Kata Ibrani yang digunakan adalah כְרָגַע ( $\left.\underline{k}^{e} r \bar{a} \bar{g} a^{c}\right)$ yang berasal dari kata רגֵ yang artinya "sebentar, tiba-tiba." ${ }^{56}$ Kehancuran orangfasik disebabkan karena kengerian (Ibr.

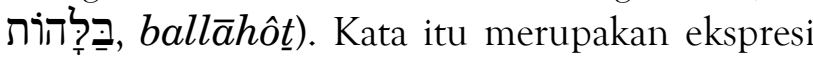
dari kematian yang dalam Ayub 18:14 dipersonifikasikan sebagai "raja kengerian." Jadi semua jenis kengerian atau kesulitan akan mendekati orang fasik dan pada akhirnya kematian itu sendiri yang akan mereka alami.

Ketiga, akhir hidup orang fasik akan dilupakan Allah (73:20). Hidup orang fasik digambarkan seperti mimpi yang mempunyai arti ketika seseorang tidur, tetapi ketika bangun rupa

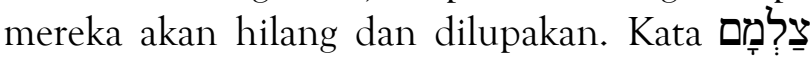

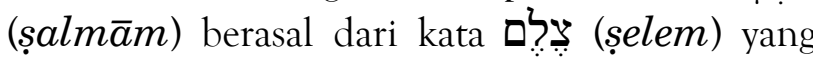
artinya "bayangan, bentuk tanpa substansi." 58 Hidup orang fasik seperti bayangan semu belaka yang hina. Oleh sebab itu VanGemeren menganggap orang fasik seperti "hantu atau setan" yang hari ini ada dan besok pergi. ${ }^{59}$ Allah akan melupakan hidup orang fasik. Pemazmur diingatkan bahwa kemakmuran orang fasik hanya sesaat karena kemakmuran mereka tidak lain dari sebuah mimpi dan akhir masa depan mereka adalah suatu realitas yang menakutkan. 333.

${ }^{56}$ Holladay, A Concise Hebrew and Aramaic Lexicon,

${ }^{57}$ Tate, Psalms 51-100, Word Biblical Commentary, 229; bnd. VanGemeren, "Psalms," dalam The Expositor's Bible Commentary, 5:481.

${ }^{58}$ Holladay, A Concise Hebrew and Aramaic Lexicon, 306.

${ }^{59}$ VanGemeren, "Psalms," dalam The Expositor's Bible Commentary, 5:481.
Keadaan Akhir Orang Benar yang Makmur (Mzm. 73:21-26)

Perspektif kedua yang dibukakan Allah kepada pemazmur berkenaan dengan keadaan hidup orang benar. Asaf sekarang memandang keadaannya sendiri dalam suatu pandangan yang sama sekali berbeda. Ia mengawali dengan suatu evaluasi terhadap reaksinya tentang kemakmuran orang fasik (73:21-22) dan dilanjutkan dengan kebenaran tentang kemakmuran yang sejati bagi orang benar (73:23-26).

\section{Evaluasi Diri Orang Benar (73:21-22)}

Ada tiga ungkapan yang menggambarkan evaluasi pemazmur terhadap reaksinya. Pertama, "hatiku menjadi sakit." Kemunculan kembali

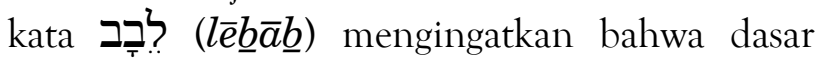
permasalahan pemazmur adalah masalah hati dan sekarang ia akui secara terbuka. Pemazmur mengakui rasa sakit hatinya yang mendalam karena kecemburuannya.

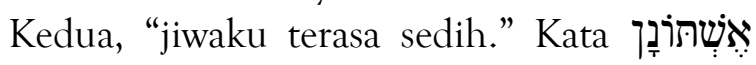

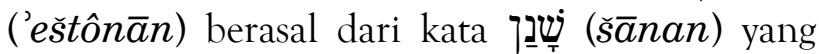
dalam bentuk Hithpolel berarti "merasa tertusuk dengan tajam." ${ }^{60}$ Tate menjelaskan bahwa kata ini merupakan sebuah metafora bagi penderitaan yang mendalam. Hati dan jiwa pemazmur menjadi sakit dan sedih karena kecemburuannya terhadap kemakmuran orang-orang fasik.

Ketiga, "aku bodoh dan tidak tahu." Asaf merasa bodoh dan tidak tahu, bahkan menggambarkan dirinya seperti binatang (Ibr.

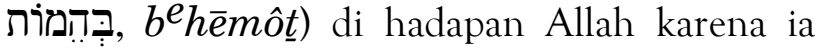
berpikir bahwa orang fasik akan lolos dengan dosa mereka dan tanpa pembalasan. Ketika perspektifnya diperbarui oleh Allah, ia merasa dirinya begitu bodoh dengan menyimpulkan bahwa Allah sedang menghukumnya agar menghindari jalan-jalan orang fasik yang penuh dengan dosa. Pemazmur juga merasa bodoh karena selama ini ia menganggap dirinya lebih benar dan saleh dibanding orang fasik. Tetapi ketika dia menyembah Allah dalam bait suci, ia

\footnotetext{
${ }^{60}$ Holladay, A Concise Hebrew and Aramaic Lexicon,
} 379. 
dipaksa untuk memandang dirinya dalam perbandingan dengan Allah.

\section{Kemakmuran Sejati Orang Benar (73:23-26)}

Penyingkapan perspektif yang baru tentang kemakmuran sejati orang benar diawali dengan adanya kerinduan yang besar dari pemazmur untuk berada dekat dengan Allahnya (73:23a). Meskipun Asaf merasa sakit hati dan sedih jiwanya, bodoh dan tidak tahu apa-apa, tetapi ia ingin selalu dekat dengan Allahnya. Kerinduan

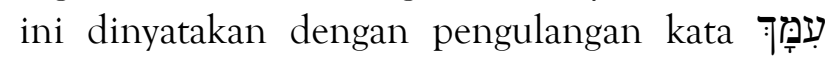
('imm $\bar{a} \underline{k}$ ) yang artinya "denganMu” sebanyak dua kali (73:23, 25). VanGemeren menjelaskan bahwa kata ini menyatakan "sukacita pemazmur akan persekutuan dengan Allah." ${ }^{\circ 1}$

Kemakmuran sejati orang benar dijelaskan secara berbeda dengan kemakmuran orang fasik. Jika kemakmuran orang fasik lebih kepada hal yang sifatnya materi dan jasmani, maka kemakmuran bagi orang benar adalah kedekatan Allah dengannya. Kemakmuran sejati orang benar dinyatakan dalam beberapa istilah penting yang menggambarkan perlindungan dan tuntunan Allah terhadap orang benar. Pertama, Allah melindungi pemazmur dengan memegang tangan kanannya (73:23). Bentuk perfek dari

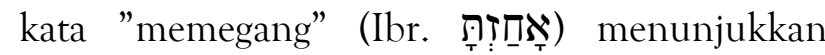
bahwa selama ini Allah telah melindungi pemazmur meskipun ia merasa seolah-olah tidak diperhatikan dan tidak diperlakukan adil oleh Allah. Asaf baru menyadari fakta ini karena sebelumnya perspektifnya telah dibutakan oleh kecemburuan terhadap orang fasik. Dia tidak bisa memahami betapa setia Allah melindunginya agar tidak jatuh dalam kecemburuan dengan mengikuti cara hidup orang fasik.

Kedua, Allah akan menuntun pemazmur (73:24a). Dalam kaitannya dengan ayat 24,

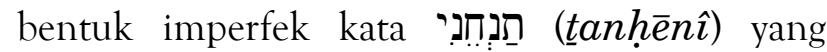
artinya "menuntun" menunjukkan penyertaan Allah yang sedang dan akan dinyatakan kepada pemazmur. Pernyataan dalam ayat $24 a$ juga merupakan keyakinan iman pemazmur berdasarkan fakta perlindungan Allah (73:23b).

\footnotetext{
${ }^{61}$ VanGemeren, "Psalms," dalam The Expositor's Bible Commentary, 5:482.
}

Tuntunan Allah kepada pemazmur dinyatakan dalam nasehatNya.

Ketiga, Allah akan membawa pemazmur dalam kemuliaan (73:24b). Kata כָָּ (kāâô $\underline{d})$ yang artinya "kemuliaan" mengandung pengertian "kehormatan." 62 Pemazmur yakin bahwa tangan Allah yang penuh perlindungan akan menuntunnya ke tempat terhormat.

Keempat, Allah memberikan ketabahan dari dalam (73:26b). Allah digambarkan sebagai batu karang hati pemazmur yang memberikan ketabahan di saat-saat yang sulit. Hal ini menunjukkan perlindungan Allah bagi hati pemazmur dalam penderitaannya.

Kelima, Allah menyediakan seluruh kebutuhan pemazmur (73:26b). Allah bukan saja memberikan ketabahan di saat-saat pemazmur mengalami kesusahan, tetapi Dia juga menyediakan seluruh kebutuhan yang diperlukan oleh pemazmur dengan kata "bagianku." Inilah kemakmuran sejati bagi orang benar. Kemakmurannya tidak semata-mata bersifat materi dan jasmani, melainkan ketika Allah dekat dengan orang benar dan campur tangan dalam hidupnya.

\section{Reorientasi Terhadap Kebaikan Allah (Mzm. 73:27-28)}

Jawaban Allah kepada pemazmur bukan hanya tentang keadaan orang fasik dan keadaan orang benar saja, tetapi orientasinya tentang kebaikan Allah juga diperbarui. Pemazmur dengan tegas mengatakan bahwa siapa saja yang hidupnya menyimpang dari jalan Allah akan mengalami kebinasaan. Allah sendiri yang akan membinasakan mereka yang berzinah dari Dia. Kata seru הִּנִ (hinnēh) muncul kembali di ayat 27 sama seperti ayat 12. Kata seru ini mempunyai fungsi untuk memberikan perhatian khusus. ${ }^{63}$ Asaf memfokuskan perhatiannya kepada akibat dari cara hidup orang fasik. Ini

${ }^{62}$ Robert B. Chisholm, Jr., "Teologi Kitab Mazmur," dalam A Biblical Theology of the Old Testament, peny. Roy B. Zuck, pen. Suhadi Yeremia (Malang: Penerbit Gandum Mas, 2005), 512-513.

${ }^{63}$ Weber, "הִּנִה" dalam Theological Wordbook of the Old Testament, 1:506. 
berbeda dengan ayat 12 yang memfokuskan perhatian kepada cara hidup orang fasik.

Akibat dari cara hidup orang fasik yang menyimpang digambarkan melalui dua kata. Pertama, "akan binasa." Bentuk imperfek kata

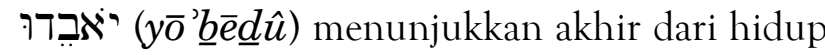
orang fasik yang sedang dan akan binasa. Kedua, "Engkau telah memusnahkan." Bentuk hiphil kata הִצְמָמָתָה (hiṣematāh) mempunyai fungsi kausatif $^{64}$ yang menunjukkan bahwa Allahlah penyebab orang fasik musnah. Sedangkan bentuk perfek mempunyai arti bahwa tindakan Allah untuk memusnahkan orang fasik merupakan ketetapan Allah untuk menghukum orang-orang yang berhubungan dengan ilah-ilah lain. ${ }^{65}$ Dari kedua kata tersebut dapat disimpulkan bahwa akibat dari cara hidup orang fasik yang menyimpang adalah kebinasaan. Kebinasaan itu sedang dan akan melanda mereka karena Allah telah menetapkan mereka yang menyimpang untuk binasa.

Sekarang pemazmur memahami kebaikan Allah dengan cara yang sangat berbeda dari ayat 1. Hal ini diawali dengan kemunculan kembali

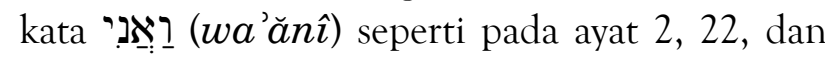
23. Kata ini memperkenalkan dan menegaskan perspektif serta komitmen pemazmur yang diperbarui. Perspektifnya dinyatakan dalam frase

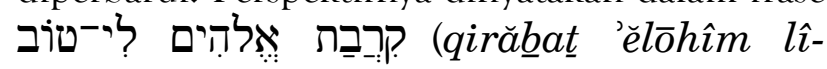
tôb) yang artinya "dekat Allah adalah baik." Perspektifnya tentang kebaikan Allah telah diperbarui oleh Tuhan. Jika dalam ayat 1 kata "baik" berarti ketidakhadiran penderitaan, maka dalam ayat 28 kata "baik" berarti kehadiran Allah dalam hidupnya lebih dari sekedar kemakmuran fisik. Bagi pemazmur kedekatan Allah atau persekutuan dengan Allah adalah kebaikan yang tertinggi.

Pembaruan perspektif tentang kebaikan Allah menghasilkan komitmen yang baru kepada Allah. Komitmen tersebut dinyatakan dalam dua

\footnotetext{
${ }^{64}$ Arnold dan Choi, A Guide to Biblical Hebrew Syntax: Second Edition, 59-60.

${ }^{65}$ Kata "berzinah" diterjemahkan dari kata זִנִִ

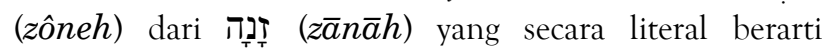
"berbuat zinah atau menjadi seorang wanita sundal." Pada ayat 27, kata ini mempunyai pengertian figuratif yaitu "berhubungan dengan ilah-ilah lain." Selidiki Brown, Driver, and Briggs, A Hebrew and English Lexicon, 275-76.
}

frase. Pertama, "aku menempatkan Tuhan ALLAH [sebagai] tempat perlindunganku." Kata שִׁית (šît) kembali muncul dalam ayat ini ${ }^{66}$ yang menerangkan komitmen Asaf untuk menjadikan Tuhan ALLAH sebagai tempat perlindungannya. Kata מַחְחסי (mahsî) seringkali menekankan sifat yang pasti dan komprehensif dari kemampuan Allah untuk melindungi umatNya ${ }^{67}$ Kedua, "aku menceritakan segala pekerjaanMu." Komitmen pemazmur yang kedua adalah menceritakan segala pekerjaan Allah. Pemazmur ingin menyaksikan pekerjaan Allah yang tersembunyi, dalam dan besar itu kepada orang lain. Ini mengingatkan setiap orang percaya untuk senantiasa menyaksikan karya Allah dalam hidup ini kepada setiap orang agar nama Tuhan dipuji dan dimuliakan.

\section{Kesimpulan}

Mazmur 73 adalah sebuah mazmur hikmat yang mengajarkan tentang bagaimana seharusnya orang benar bergumul dan bersikap terhadap kecemburuan akan kemakmuran orang fasik. Permasalahan orang benar berangkat dari hasil observasinya terhadap kemakmuran orang fasik. Di satu sisi dia yakin bahwa Allah adalah baik. Tetapi di sisi lain dia melihat orang fasik menjadi makmur dengan cara hidupnya yang jahat dan populer, sedangkan orang benar tidak pernah lepas dari hajaran. Akar masalahnya adalah hati. Orang benar cemburu melihat keadaan orang fasik yang makmur dengan cara hidupnya yang jahat dan populer. Hal ini sangat menyakitkan hati karena sepertinya keadaan berjalan terbalik.

Berangkat dari kecemburuannya, orang benar mulai meragukan apa yang selama ini diyakini dan dijalaninya. Tetapi pada akhirnya orang benar membuka diri dan membawa pergumulannya kepada Allah dalam tempat kudus-Nya. Persekutuan bersama dengan Allah

\footnotetext{
${ }^{66}$ Kemunculan kata שִ שִית (š̂t dalam ayat 6, 9, dan 18. Kata שִׁית (š̂t "meletakkan, memasang, menempatkan, menetapkan."

${ }^{67}$ Andrew E. Hill, "חסה" dalam New International Dictionary of Old Testament Theology and Exegesis, pen. Willem A. VanGemeren (Grand Rapids: Zondervan Publishing House, 1997), 2:219.
} 
membukakan perspektif yang baru baginya. Orang benar tahu bahwa akhir hidup orang fasik menyedihkan dan kemakmuran yang sejati hanya ada dalam persekutuan yang intim dengan Allah. Sekarang, pengertiannya tentang kebaikan Allah menjadi baru melalui perubahan perspektif yang dikerjakan oleh Allah dalam persekutuannya dengan-Nya.

\section{Kepustakaan}

Arnold, Bill T. dan John H. Choi. A Guide to Biblical Hebrew Syntax: Second Edition. Cambridge: Cambridge University Press, 2018.

Allen, Ronald B. "עָָּמָל." Dalam Theological Wordbook of the Old Testament. Disunting oleh R. Laird Harris, Gleason L. Archer dan Bruce K. Waltke. Chicago: Moody Press, 1980.

Briggs, Charles Augustus dan Emilie Grace Briggs. A Critical and Exegetical Commentary on the Book of Psalms. Dalam The International Critical Commentary. Edinburgh: T \& T. Clark, 1906.

Brown, Francis, S.R. Driver, and Charles A. Briggs. A Hebrew and English Lexicon of the Old Testament. Oxford: Clarendon Press, 1906.

Buber, Martin. "The Heart Determines: Psalm

73." Dalam Issues in Religion and Theology 4: Theodicy in the Old Testament. Disunting oleh James L. Crenshaw. Philadelphia: Fortress, 1968.

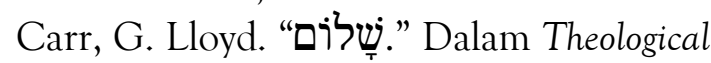
Wordbook of the Old Testament. Disunting oleh R. Laird Harris, Gleason L. Archer dan Bruce K. Waltke. Chicago: Moody Press, 1980.

Chisholm, Robert B. "Teologi Kitab Mazmur." Dalam A Biblical Theology of the Old Testament. Disunting oleh Roy B. Zuck. Diterjemahkan oleh Suhadi Yeremia. Malang: Yayasan Penerbit Gandum Mas, 2005.

Coppes, Leonard J. "נְגבגנ." Dalam Theological Wordbook of the Old Testament. Disunting oleh R. Laird Harris, Gleason L. Archer dan Bruce K. Waltke. Chicago: Moody Press, 1980. . "To Touch." Dalam Nelson's

Expository Dictionary of the Old Testament. Disunting oleh Merril F. Unger dan William White. Nashville: Thomas Nelson Publishers, 1980.

Crenshaw, James L. The Psalms: An Introduction. Grand Rapids: William B. Eerdmans Publishing Company, 2001.

Dahood, Mitchel, The Anchor Bible: Psalms II 51. 100. Garden City, NY: Doubleday \& Company, 1968.

Deffinbaugh, Robert L. "Psalm 73: The Suffering of the Righteous and the Success of Sinners." Online: http://www.bible.org/. . "The Goodness of God." Dalam Let Me See Thy Glory - A Study of the Attributes of God, online: http://www.bible.org.

Delitzsch F. Psalms, Commentary on the Old Testament in Ten Volumes. Diterjemahkan oleh James Martin. Grand Rapids: William B. Eerdmans Publishing Company, 1955.

Enns, Paul.The Moody Handbook of Theology (Buku Pegangan Teologi). Disunting oleh Rahmiati Tanudjaja. Malang: Literatur SAAT, 2003.

Hill, Andrew E. "חסה." Dalam New International Dictionary of Old Testament Theology and Exegesis. Disunting oleh Willem A. VanGemeren. Grand Rapids: Zondervan Publishing House, 1997.

Holladay, William L. A Concise Hebrew and Aramaic Lexicon of the Old Testament. Grand Rapids: William B. Eerdmans Publishing Company, 1988.

Hover-Johag, I. "טוב." Dalam Theological Dictionary of the Old Testament. Disunting oleh G. Johannes Botterweck dan Helmer Ringgren. Diterjemahkan oleh David. E. Green. Grand Rapids: William B. Eerdmans Publishing Company, 1986.

Kidner, Derek. Psalms 73-150: A Commentary on Books III-V of the Psalms. Tyndal Old Testament Commentaries. Downers Grove, Illinois: Inter-Varsity Press, 1975. 
LaSor, W.S., D.A. Hubbard, F.W. Bush. Pengantar Perjanjian Lama 2: Sastra dan Nubuat. Diterjemahkan oleh Lisda Tirtapraja Gamadi dan Lily W. Tjiputra. Jakarta: BPK Gunung Mulia, 1982.

McCann, J. Clinton. "Psalm 73: A Microcosm of Old Testament Theology." Dalam The Listening Heart: Essays in Wisdom and the Psalms in Honor of Roland E. Murphy. Diterjemahkan oleh K.G. Hogland, E.F. Huwiler, J.T. Glass, R.W. Lee, JSOTSup 58. Sheffield: JSOT, 1987.

Murphy, Roland E. Old Testament Reading Guide: Introduction to the Wisdom Literature of the Old Testament. Collegeville, Minnesota: The Liturgical Press, 1965.

. "The Listening Heart: Essays in

Wisdom and the Psalms in Honor of Roland E. Murphy, O. Carm.” Dalam Journal for the Study of the Old Testament Supplement 58. Disunting oleh Kenneth G. Hoglund. Sheffiled: JSOT Press, 1987.

Reuter E. "קנא." Dalam Theological Dictionary of the Old Testament. Disunting oleh G. Johannes Botterweck, Helmer Ringgren, dan Heinz-Josef Fabry. Diterjemahkan oleh David E. Green. Grand Rapids: William B. Eerdmans Publishing Company, 1986.

Ross, Allen P. A Commentary on The Psalms: Volume 1 (1-41). Grand Rapids: Kregel Publications, 2011. . "Psalms." Dalam The Bible Knowledge Commentary. Disunting oleh John F. Walvoord dan Roy B. Zuck. Dallas: Victor Books, 1985.

Saparman. Belajar Alkitab: Cara $\mathbb{E}$ Contoh. Yogyakarta: STII Press. 2007.

Scott, R. B. Y. The Way of Wisdom in the Old Testament. New York: Mac-Millan, 1971.

Tate, Marvin E., Psalms 51-100. Word Biblical Commentary. Dallas: Word Books Publisher, 1990.

VanGemeren, Willem A. "Psalms." Dalam The Expositor's Bible Commentary. Disunting secara umum oleh Frank E. Gaebelein. Vol. 1-5. Grand Rapids: Zondervan Publishing House, 1991.

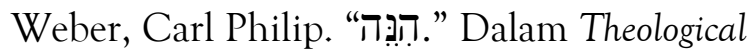
Wordbook of the Old Testament. Disunting oleh R. Laird Harris, Gleason L. Archer dan Bruce K. Waltke. Chicago: Moody Press, 1980.

Williams, Ronald J. Hebrew Syntax: An Outline. Toronto: University of Toronto Press, 1976. 